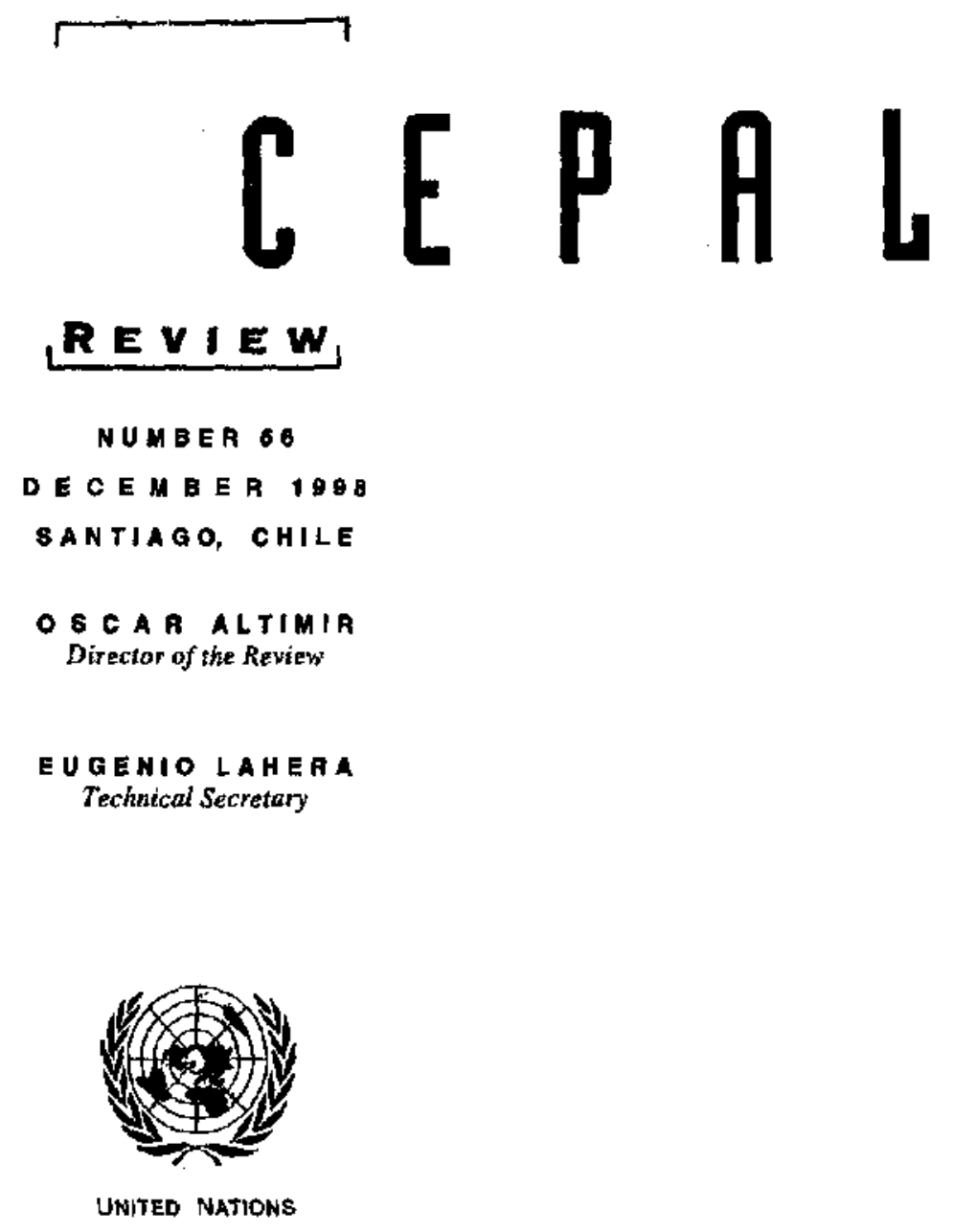


CONTENTS

Beyond the Washington Consensus: an ECLAC perspectlve

José Antonio Ocampo

The Cuban economy

David Ibarra and Jorge Máttar

Education in Latin America: demand and distribution are factors that matter

Nancy Birdsall, Juan Luis Londoño and Lesley O'Connell

Determinants of inequality among urban households

Luis Felipe Jiménez $L$, and Nora Ruedi $A$.

Health management contracts in Costa Alca from a comparative perspective

Ana Sojo

A development strategy tounded on natural resource-based production clusters

Jaseph Ramos

Blg Latin American industrial companies and groups

Celso Garrido and Wilson Peres

Between political control and efflciency gains:

the evolution of agrarian property rights in Mexico

Gustavo Gordillo, Alain de Janvry and Elizabeth Sadoulet

Tariffs and the Plano Real in Brazil

Renaso Baumann, Josefina Rivero and Yohana Zavattiero 


\section{Determinants of \\ inequality among urban households}

\section{Luis Felipe Jiménez L. Nora Ruedi A.}

Financing Unit, Intemational Trade, Transport and Finance Division, ECLAC.
This article summarizes the results of an analysis of the long-term factors affecting income distribution in five countries of the region (Argentina, Brazil, Chile, Colombia and Mexico), on the basis of household surveys made in those countries between 1979 and 1992. After a brief introduction (section I), the article describes the methodology applied (section II) and then details the main findings (section III). These include in particular the lower labour remumeration received by the first income deciles, associated among other things with inequalities in the educational levels attained. It is also observed that those deciles have below-average employment rates and above-average rates of inactivity. This latter phenomenon appears to be connected with household composition: the first deciles register a relatively greater presence of minors in the household, so that the burden of looking after children is greater and the cost of participating in the labour market is higher, thus leading to lower participation in it and reducing income generation. The article concludes with some suggestions for a redistribution policy (section IV). Such a policy should seek to advance simultaneously in at least four fields: generation of productive employment, improvement of the income of the poorest households, lowering of the barriers hindering such households' access to the labour market and, finally, aspects related with population dynamics. 


\section{I}

\section{Introduction}

This article was motivated by three main considerations. Firstly, achieving a higher degree of equity has been an important part of the objectives of the development strategies pursued by the governments of the region, expressed through their efforts to promote greater equality of opportunities and to reduce the incidence of poverty. Secondly, as already shown by other studies published in this Review, the distributive picture in the early $1990 \mathrm{~s}$, after the adjustment processes and structural reforms of the 1980s, displays a disquieting deterioration (Altimir, 1994), and securing its recovery from this situation represents an important challenge for governments and their policies. Thirdly, the evolution of income distribution in the region in the first half of the 1990s continues to be discouraging in general terms, although there has been some progress in a few isolated cases (ECLAC, 1994a and 1995). Furthermore, the low economic growth rates registered in some cases and the consequent increase in unemployment rates (ILO, 1996) give grounds for expecting that income distribution could deteriorate still further in some countries.

Consequently, policies aimed at overcoming this situation take on renewed importance in view of both the long-term nature of certain factors affecting income distribution ${ }^{1}$ and the urgent need to take measures which will make it possible to improve the situation of the poorest groups in the medium term, given the seriousness of their current circumstances.

This article addresses one of the dimensions of equity, analysing factors which help to give an idea of the differences in per capita housebold income in five countries of the region. Various studies on income distribution have examined factors which could explain inequalities between income recipients. In the present study, however, the unit of analysis is the household, including both people who receive income and those who do not do so. The analysis is centered, then, on determining how per capita household income is made up. The variables considered include levels of remuneration, the incorporation in employment and rates of participation of the members of the household, and demographic aspects which affect the size of households. The study also examines aspects related with inequalities in factor remuneration, not only as they relate to the characteristics of the income recipients but also, and particularly, in terms of their effect on per capita household income.

It should be borne in mind that, although a common methodology is used, the analysis is not designed to establish distributional comparisons between countries; the aim is rather to identify regularities in the behaviour of certain variables which can help to explain the income distribution in a particular country. At the same time, with the aim of obtaining conclusions which will have a certain degree of general validity, this synthesis is based on the results obtained for the main urban centres of the five countries studied. As the coverage of the surveys varies greatly from one country to another, ${ }^{2}$ it was decided to restrict the analysis to those centres when comparing the results, in order to establish conclusions applicable to other cases.

$\square$ This document summarizes the results of studies made under the Netherlands Government/ECLAC project on "Income distribution and poverty in recent cases of stabilization and adjustment in Latin American and Caribbean countries". The individual studies for Argentina, Brazil, Chile, Colombia and Mexico were published separately (Jiménez and Ruedi, 1997a, b, c, d and e). In carrying out these studies, the authors enjoyed the support of the ECLAC Division of Statistics and Economic Projections. The authors wish to express their gratitude to Oscar Altimir, Juan Carlos Feres and Carlos Howes for their valuable comments and collaboration.

\footnotetext{
I With regard to the influence of short-term factors and policies on income distribution, see Jiménez (1997).

${ }^{2}$ For example, the results for Argentina refer to Buenos Aires, whereas the surveys for Brazil and Chile include rural areas as well as the metropolitan areas.
} 


\section{II}

\section{The method of analysis used}

In order to strengthen the comparability of this study, a methodology was used which bad previously been employed by Pollack and Uthoff (1990) in their study of income distribution in Greater Santiago, Chile. In the present case, the methodology was applied to the household surveys available for the period 1979-1992 in Argentina, Brazil, Chile, Colombia and Mexico. This approach is based on a set of common indicators which is simple but has the merit of identifying some key factors which affect the level of household income. The methodology is basically descriptive and seeks to detect regularities in the behaviour of certain variables associated with income distribution. It does not, therefore, involve the application of a theoretical approach which assumes a priori the existence of a certain order of causality, although the interpretation of the results, based on the identification of systematic differences of behaviour between deciles, does depend on explanatory hypotheses of the origins of inequality and changes in it.

Per capita household income may be expressed in simplified form through the following equation:

$$
Y p c=\frac{Y T}{N}=\frac{Y P}{L} \times \frac{L}{L+D} \times \frac{L+D}{P E T} \times \frac{P E T}{N} \times \frac{O Y}{N}
$$

where:

$$
\begin{array}{ll}
Y p c & =\text { per capita household income } \\
Y T & =\text { total disposable household income } \\
N & =\text { number of persons in household } \\
Y P & =\text { primary income of the employed persons } \\
& \text { in the household } \\
L & =\text { number of employed persons in the } \\
& \text { household } \\
D & =\text { number of non-employed persons in the } \\
& \text { household } \\
P E T \quad= & \text { number of persons of working age in the } \\
& \text { household } \\
O Y \quad & =\text { other household income. }
\end{array}
$$

Thus, the per capita household income is expressed as a function of economic and demographic variables. The first term on the right-hand side, $Y P / L$, corresponds to the average remuneration received by the employed persons in the household. This primary income is composed in turn of labour income (wages, salaries and own-account labour income). It thus, corresponds to a concept of average factor remuneration per employed person.

The second term on the right-hand side, $L(L+D)$, is the rate of employment of the household, its complementary indicator being the rate of unemployment. The third term, $(L+D) / P E T$, is the rate of participation. The fourth term is the ratio of the number of persons of working age in the household to the size of the household, $P E T / N$. The inverse to this factor is an approximation to the rate of dependence of the household, in the sense discussed in the following paragraph. The higher this ratio, the greater the number of persons of an age capable of giving economic support to the household, thus giving a lower rate of dependence.

This concept of the rate of dependence has a demographic connotation, in contrast with other uses which emphasize different aspects. Thus, this rate is often referred to as the ratio between the number of employed persons and the number of persons who do not work in a given group, thus highlighting the economic effort that the employed persons have to make to support the rest of the household. The relevant variables in this respect will be the rates of employment and wages, which are already included in the first two factors of the equation. In the present case, the ratio between the number of persons of working age and the size of the household represents the proportion of the household potentially capable of supporting it, with the age structure and the size of the household being the relevant variables in this respect.

Finally, the last factor corresponds to income received from sources other than labour, i.e., income from ownership of property and from transfers, both in per capita terms. The transfers correspond to subsidies received and income from pensions.

The differences by deciles in the levels of per capita family income are thus expressed as a function of the behaviour of the rates of factor remuneration, employment and participation in the labour force, of 
a variable relating to the demographic structure of the household, and of an "other income" component. Changes in income distribution are thus linked with the evolution of these components over time. Consequently, households were ordered according to their per capita income and the factors making up this equation were calculated. Since these factors reflect the influence of many variables, however, additional indicators were calculated which help to explain the differences in the primary income levels, rates of participation and structure of the households.

For a better understanding of the differences in primary income by deciles (with the households ordered by their per capita income), the components of such income were calculated, i.e., the average wages and salaries of the wage-earning members of the households and the average income of own-account workers. The average income from ownership of property was also calculated, thus completing the sources of income by factors.

Other theoretical and applied approaches have been aimed at explaining the differences in income among recipients in the light of characteristics connected with the educational level of workers. In the present study, in order to explore how this factor could help to explain differences in per capita income between household deciles, the structure of the households in each decile was examined in the light of the educational level of the head of household.

Furthermore, in order to seek variables which could cause differences in rates of employment and participation, the behaviour of the households in each decile was examined according to the type of activity of the head of household and his or her spouse. In the latter case, the calculations were restricted to spouses of employed heads of household, in order to analyse the capacity of the couple to provide economic support for the household.

Finally, with the aim of investigating the possible influence of household structure on other variables, calculations were made, by household deciles, of the proportion of children to adults and the average number of persons in the household.

Some observations are called for on the concept of income used here. Firstly, the figures used here include the adjustments made by ECLAC with the aim of making this information compatible with that taken from the national accounts. In general terms, the procedure consists of imputing income as necessary in order to correct the discrepancies which arise when the items in the household account of the system of national accounts are compared with those obtained from household surveys (Feres, 1995; ECLAC, 1991 and 1996b).

Secondly, the surveys record income after deduction of taxes and social security contributions, but include transfers and donations received. Thirdly, imputed rent has been excluded, since the imputation is effected at the level of the households, whereas the selected indicators refer mainly to average characteristics of the members of the household as regards their capacity for generating income.

Finally, the income recorded in the surveys includes that attributable to ownership of property. Experience shows, however, that the surveys reflect the income from ownership of property to a considerably smaller extent than in the case of the other components of income. As the difficulties of measurement in this respect are made worse by situations of serious inflation, such as those which affected countries in the region during the period studied, it would be risky to generalize on the basis of such data. Consequently, the analysis concentrates on the other components of household income.

In view of the interest aroused by income distribution and the factors accounting for it, the statistical tables present relative indexes, using the average value of each variable for the entire sample as the reference pattern. This makes it possible to show how much the average variable for each decile differs with respect to the overall sample. 


\section{III}

\section{Main comparatlve results}

Table 1 briefly presents some features of income distribution between 1980 and 1992 in the main urban centres" of the five countries studied. As may be seen from the table, during this period - much of which was marked by considerable macroeconomic fluctuations associated with the external indebtedness crisis affecting the countries of the region- there were significant changes in income distribution. According to the Gini coefficient, income concentration in the main urban centres went down in Colombia, increased in Argentina, Brazil and Mexico, and tended to remain unchanged, with some oscillations, in Chile.

The changes in the shares of the top and bottom deciles in total income are more enlightening. ${ }^{4}$ If we look at the case of Colombia -a country which registered a reduction in income concentration during this period-we see that there was a redistribution of around $7 \%$ of income from the top decile, mainly to the upper middle deciles, with the share of the lower deciles increasing only slightly (see Jiménez and Ruedi, 1997b). It should be noted, however, that redistributions of this size are highly significant; when applied to a growing GDP, they represent a substantial transfer of income to the upper middle sectors. Other indicators reflect a somewhat more positive evolution. Thus, the average per capita income of the first decile increased from $8.9 \%$ of the average for the whole to $12 \%$. At the same time, the real income of this segment increased by $68.2 \%$, while the total rose by only $24.8 \%$. Probably because of the low initial level of the per capita income of the lower strata, however, the increase in income was not sufficient to reduce the incidence of poverty in urban households. In short, a process of redistribution was observed in Colombia, but it did not reach the poorer strata to a significant extent. ${ }^{5}$

\footnotetext{
${ }^{3}$ In the case of Mexico, the areas selected were those of high population density.

4 Purely for illustrative purposes, it may be noted that most of the tables in this article present information on the top and bottom deciles, although the conclusions are based on the observation of distribution as a whole, as it appears in the national case studies summarized here.

5 Ocampo, Pérez, Tovar and Lasso (1998) note that although income distribution improved in the urban sectors, there was a deterioration in rural areas.
}

In the countries where there was an increase in concentration in this period (Argentina, Brazil and Mexico), there were reductions in the share of the bottom decile (and, in certain cases, significant redistributions in favour of the top decile), increases in the differences in per capita income between the bottom decile and the top decile with respect to the mean, real losses of income in the first decile, and increases in the incidence of poverty.

In Chile, for its part, there were variations in distribution which are not fully expressed by changes in the Gini coefficient. Thus, the share of the bottom decile increased slightly, but less than the increases in the share of the top decile. Moreover, although the per capita income of the first decile increased as a percentage of the mean, that of the top stratum also rose, so that it drew still further away from the rest. In the context of growth registered at the time, the real per capita income of the first stratum rose faster than the average and at the same time there was a reduction in the percentage of households in a state of poverty. The top decile also registered increases greater than the mean, however, thus ruling out any possible improvement in distribution. In short, as other studies have also noted (ECLAC, 1997), the Chilean experience may be considered as a process of growth with reduction of poverty but little redistributive content. Hypotheses will be established later in this article which help to explain the low degree of social dissemination of growth observed in some countries of the region.

In short, except in the case of Colombia, there was an increase in the differences in income between the two extremes of the distribution scale during the period studied. In all cases, however, the share of the first deciles remained at a very low level. Once again with the exception of Colombia, the redistributions of income which took place consisted of very significant increases in the share of the top decile, equivalent in some cases to between two and three times the total share of the botton decile. The low shares of the poorest groups in total income also persisted strongly over time: a phenomenon which was repeated in all the countries and caused income distribution to display great inertia. Finally, during the period in ques- 
Latin America (five countries): Indicators of income distribution

\begin{tabular}{|c|c|c|c|c|c|c|c|c|c|}
\hline & \multirow{2}{*}{$\begin{array}{l}\text { Gini } \\
\text { coeff- } \\
\text { icient }\end{array}$} & \multicolumn{2}{|c|}{$\begin{array}{l}\text { Share in total } \\
\text { income }\end{array}$} & \multicolumn{2}{|c|}{$\begin{array}{l}\text { Ratio of average } \\
\text { per capita income to } \\
\text { the overall average }\end{array}$} & \multicolumn{3}{|c|}{$\begin{array}{l}\text { Index of average } \\
\text { real per capita } \\
\text { income }\end{array}$} & \multirow{2}{*}{$\begin{array}{l}\text { Percentage } \\
\text { of house- } \\
\text { holds under } \\
\text { the poverty } \\
\text { line (total, } \\
\text { urban } \\
\text { areas) }\end{array}$} \\
\hline & & $\begin{array}{l}\text { First } \\
\text { decile }\end{array}$ & $\begin{array}{c}\text { Top } \\
\text { decile }\end{array}$ & $\begin{array}{c}\text { First } \\
\text { decile }\end{array}$ & $\begin{array}{c}\text { Top } \\
\text { decile }\end{array}$ & $\begin{array}{c}\text { Total } \\
\text { sample }\end{array}$ & $\begin{array}{l}\text { First } \\
\text { decile }\end{array}$ & $\begin{array}{c}\text { Top } \\
\text { decile }\end{array}$ & \\
\hline \multicolumn{10}{|l|}{ Argentina (Buenos Aires) } \\
\hline 1980 & 0.365 & 3.0 & 30.6 & 22.0 & 360.0 & 100.0 & 100.0 & 100.0 & $s^{b}$ \\
\hline 1986 & 0.393 & 2.0 & 34.0 & 19.2 & 407.2 & 104.6 & 91.2 & 118.3 & $9^{b}$ \\
\hline 1990 & 0.422 & 2.3 & 34.2 & 15,4 & 411.9 & 92.3 & 64.5 & 105.6 & $16^{b}$ \\
\hline 1992 & 0.408 & 2.3 & 31.6 & 15.6 & 399.5 & 89.1 & 63.3 & 98.9 & $10^{b}$ \\
\hline \multicolumn{10}{|l|}{ Brazil (Sâo Paulo and Rio de Janeiro) } \\
\hline 1979 & 0.448 & 2.1 & 36.1 & 12.9 & 432.3 & 100.0 & 100.0 & 100.0 & 30 \\
\hline 1987 & 0.526 & 1.4 & 44.0 & 9.7 & $\$ 29.1$ & 115.0 & 86.8 & 140.8 & 34 \\
\hline 1990 & 0.503 & 1.5 & 37.6 & 9.7 & 467.2 & 99.7 & 75.2 & 107.7 & 37 \\
\hline \multicolumn{10}{|l|}{ Chile (Grealer Santiago) } \\
\hline 1987 & 0.507 & 1.4 & 40.0 & 9.9 & 471.9 & 100.0 & 100.0 & 100.0 & 38 \\
\hline 1990 & 0.487 & 1.7 & 39.6 & 12.3 & 440.5 & 110.6 & 138.2 & 103.3 & 33 \\
\hline 1992 & 0.512 & 1.7 & 44.4 & 12.4 & 489.3 & 136.0 & 170.3 & 141.1 & 28 \\
\hline \multicolumn{10}{|l|}{ Colombia (Bogotă) } \\
\hline 1980 & 0.520 & 1.3 & 40.8 & 8.9 & 489.2 & 100.0 & 100.0 & 100.0 & $36^{\circ}$ \\
\hline 1986 & 0.457 & 1.5 & 36.2 & 10.5 & 443.6 & 121.4 & 142.5 & 110.0 & $36^{\mathrm{c}}$ \\
\hline 1990 & 0.478 & 1.4 & 36.0 & 10.3 & 437.1 & 120.9 & 139.2 & 108.0 & $35^{\mathrm{c}}$ \\
\hline 1992 & 0.448 & 1.8 & 34.0 & 12.0 & 433.8 & {$[24.8$} & 168.2 & 110.7 & $38^{d}$ \\
\hline \multicolumn{10}{|l|}{ Mexico (high density areas) } \\
\hline 1984 & 0.324 & 3.1 & 26.7 & 18.2 & 358.3 & 100.0 & 100.0 & 100.0 & 28 \\
\hline 1989 & 0.432 & 2.4 & 37.6 & 14.7 & 460.8 & 101.4 & 82.0 & 130.4 & 34 \\
\hline 1992 & 0.426 & 2.4 & 36.2 & 15.4 & 424.4 & 114.1 & 96.4 & 135.1 & 30 \\
\hline
\end{tabular}

Source: ECLAC, on the basis of special tabulations of household surveys.

"ECLAC, 1997. ${ }^{\mathrm{b}}$ Metropolitan areas.

${ }^{d}$ Eight main cities.

tion only Chile registered a reduction in urban poverty, whereas in the other countries this increased still further or remained unchanged.

\section{Stylized features of the relative levels of income}

\section{a) Components of primary income}

Table 2 presents details of the components of primary income and transfers. It confirms the influence of remuneration for wage labour on income distribution. Thus, in the countries where the relative differences in this variable are smaller (Argentina and Mexico), the share of the first decile in total income tends to be greater. At the same time, from a time perspective, in the countries where distribution deteriorated (Argentina, Brazil and Mexico) there was a further increase in the relative differences in wage remuneration per employed person.

The average income from own-account labour displays relative differences between the deciles which are even more pronounced than in the preced- ing case and have generally tended to grow still larger over time (table 2). Such income typically represents a growing proportion of the total by deciles, probably due to the greater heterogeneity of the type of work which gives rise to this source of income. Thus, among the upper strata, this class of income usually includes income from independent professional activities and rents of employers, while among the lower strata it mostly corresponds to relatively unskilled own-account workers.

In short, the inequality of household per capita income corresponds largely to disparities in the remuneration to labour, although this is not the only determining factor, as we shatl see later in this article. In turn, changes in the differences in relative remunerations are reflected in fluctuations in distribution, with such fluctuations being smaller when the poorest deciles have a larger share in total income.

The factors influencing differences in remuneration are of various types and have been dealt with in a number of studies. Firstly, the most robust results refer to the influence of the educational 
Latin Amerlos (five countries): Rolative indexes of the factors making up household Income a

\begin{tabular}{|c|c|c|c|c|c|c|c|c|}
\hline & \multicolumn{2}{|c|}{$\begin{array}{l}\text { Average primary } \\
\text { incomefaverage } \\
\text { total income }\end{array}$} & \multicolumn{2}{|c|}{$\begin{array}{c}\text { Average wage } \\
\text { incometaverage } \\
\text { total income }\end{array}$} & \multicolumn{2}{|c|}{$\begin{array}{l}\text { Average own-aceount } \\
\text { income/average total } \\
\text { income }\end{array}$} & \multicolumn{2}{|c|}{$\begin{array}{l}\text { Average incume } \\
\text { from transfers/ } \\
\text { average total income }\end{array}$} \\
\hline & $\begin{array}{c}\text { First } \\
\text { decile }\end{array}$ & $\begin{array}{c}\text { Top } \\
\text { decile }\end{array}$ & $\begin{array}{c}\text { First } \\
\text { decile }\end{array}$ & $\begin{array}{c}\text { Top } \\
\text { decile }\end{array}$ & $\begin{array}{c}\text { First } \\
\text { decile }\end{array}$ & $\begin{array}{c}\text { Top } \\
\text { decile }\end{array}$ & $\begin{array}{l}\text { First } \\
\text { decile }\end{array}$ & $\begin{array}{c}\text { Top } \\
\text { decile }\end{array}$ \\
\hline \multicolumn{9}{|l|}{ Argentina (Buenos Aires) } \\
\hline 1980 & 40.1 & 241.3 & 60.9 & 202.5 & 9.4 & 350.8 & 61.7 & 172.2 \\
\hline 1986 & 32.0 & 303.2 & 38.6 & 199.0 & 14.2 & 467.0 & 87.1 & 153.7 \\
\hline 1990 & 25.9 & 321.8 & 39.8 & 202.0 & 6.8 & 452.3 & 86.9 & 119.9 \\
\hline 1992 & 25.3 & 291.4 & 41,0 & $18 ! .2$ & 4.1 & 397.4 & 83.3 & 185.4 \\
\hline \multicolumn{9}{|l|}{ Brazil (São Paulo and Rio de Janeiro) } \\
\hline 1979 & 26.9 & 323.1 & 32.1 & 289.9 & 9.0 & 471.3 & 21.3 & 362.4 \\
\hline 1987 & 14.8 & 385.7 & 23.6 & 323.4 & 7.5 & 478.3 & 20.2 & 462.9 \\
\hline 1990 & 19.9 & 342.9 & 22.7 & 305.5 & 10.1 & 452.3 & 19.3 & 435.2 \\
\hline \multicolumn{9}{|l|}{ Chile (Greater Santiago) } \\
\hline 1987 & 16.4 & 422.4 & 21.0 & 325.5 & 9.3 & 655.3 & 22.8 & 287.6 \\
\hline 1990 & 23.4 & 404.3 & 28.5 & 321.5 & 9.4 & 551.3 & 30.4 & 224.5 \\
\hline 1992 & 23.2 & 448.9 & 32.8 & 320.1 & 7,0 & 602.3 & 21.3 & 301.7 \\
\hline \multicolumn{9}{|l|}{ Colombia (Bogotí) } \\
\hline 1980 & 18.1 & 391.6 & 24,1 & 302.9 & 9.1 & 465.3 & 42.2 & 315.1 \\
\hline 1986 & 22.6 & 327.1 & 29.1 & 271.4 & 8.7 & 421.6 & 17.0 & 374.0 \\
\hline 1990 & 23.0 & 317.7 & 25.5 & 239.5 & 9.6 & 384.5 & 10.4 & 392.9 \\
\hline 1992 & 31.1 & 308.0 & 37.3 & 254.5 & 14.6 & 371.7 & 6.7 & 398.8 \\
\hline \multicolumn{9}{|l|}{ Mexico (high density areas) } \\
\hline 1984 & 35.4 & 262.3 & 42.7 & 188.2 & 16.3 & 372.4 & 42.0 & 259.1 \\
\hline 1989 & 29.8 & 377.5 & 45.3 & 210.8 & 7.5 & 573.7 & 23.0 & 318.5 \\
\hline 1992 & 27.6 & 411.3 & 41,6 & 243.9 & 7.7 & 614.7 & 25.9 & 242.6 \\
\hline
\end{tabular}

Source: ECLAC, on the basis of special tabulations of household surveys.

"These indexes are ratios between the average value of the variable for the decile in question and the corresponding overal average.

variable. ${ }^{6}$ Table 3 shows income distribution in Brazil, Chile and Colombia according to the educational level of the heads of household, by deciles. ${ }^{7}$ As may be seen from the table, there is a systematic association between the levels of education attained and the income decile that the head of household belongs to: the higher his level of education, the greater the possibilities his household will have of belonging to a decile with higher per capita income.

Secondly, in the context of segmented markets, the remuneration to human capital also differs according to the segment of the labour market in which the worker operates. Thus, for a given level of skills, the remuneration will depend on the type of occupation and the size and the ownership of the enterprise

${ }^{6}$ See, for example, Altimir and Piñera (1977) and also Psacharopoulos, Morley, Fiszbein, Lee and Wood (1992).

${ }^{7}$ The information for Argentina and Mexico is based on a classification by educational levels which is different from that used in this table, so that this information is not comparable. Nevertheless, the results still hold good. See the case studies for these countries in this same series.
(Altimir and Piffera, 1977). There is also ample evidence that the lower income groups are located to a greater extent in sectors of low productivity and growth, thus giving rise to lower remuneration for a given level of skills. In fact, between $40 \%$ and $60 \%$ of the employed urban population works in lowproductivity segments, especially micro-enterprises and unskilled own-account work (ECLAC, 1996a).

In short, the differences in household per capita income are partly the result of inequalities in remuneration of labour, which originate in turn in differences in levels of skills and location in the less dynamic segments of the labour market.

\section{b) The relative level of transfers}

Table 2 also provides information on average transfers per recipient (pensions and other income) in the top and bottom deciles, as well as showing their relative evolution over the period studied. The results for Argentina, which showed smaller relative differences, are noteworthy in this respect; indeed, in this case these transfers would appear to have helped 
TABLE 3

Latin America (three countrles): Distributlon of households

by years of schooling of head of household, by declles

(Percentages)

\begin{tabular}{|c|c|c|c|c|c|c|c|c|c|c|c|c|}
\hline & \multicolumn{4}{|c|}{ Brazil, 1990* } & \multicolumn{4}{|c|}{ Colombia, $1992^{b}$} & \multicolumn{4}{|c|}{ Chile, 1992} \\
\hline & $\begin{array}{c}0-3 \\
\text { years }\end{array}$ & $\begin{array}{c}4-9 \\
\text { years }\end{array}$ & $\begin{array}{l}10-12 \\
\text { years }\end{array}$ & $\begin{array}{l}13 \text { or } \\
\text { more }\end{array}$ & $\begin{array}{c}0-3 \\
\text { years }\end{array}$ & $\begin{array}{c}4-9 \\
\text { years }\end{array}$ & $\begin{array}{l}10-12 \\
\text { years }\end{array}$ & $\begin{array}{l}13 \text { or } \\
\text { more }\end{array}$ & $\begin{array}{c}0-3 \\
\text { years }\end{array}$ & $\begin{array}{c}49 \\
\text { years }\end{array}$ & $\begin{array}{l}10-12 \\
\text { years }\end{array}$ & $\begin{array}{l}13 \text { or } \\
\text { more }\end{array}$ \\
\hline Total & 100 & 100 & 100 & 100 & 100 & 100 & 100 & 100 & 100 & 100 & 100 & 100 \\
\hline ] & 17.9 & 5.3 & 1,2 & 0.1 & 18.3 & 12.7 & 4.7 & 1.0 & 14.5 & 13.3 & 6.8 & 2.1 \\
\hline 2 & 16.5 & 6.7 & 1.7 & 0.3 & 15.6 & 12.7 & 6.5 & 1.1 & 12.5 & 12.5 & 9.0 & 2.2 \\
\hline 3 & 14.2 & 9.0 & 3.0 & 0.4 & 15.2 & 12.3 & 7.2 & 1.7 & 12.5 & 11.6 & 9.9 & 3.1 \\
\hline 4 & 12.7 & 10.3 & 4.4 & 0.6 & 14.5 & 12.5 & 6.6 & 2.0 & 14.1 & 11.1 & 9.6 & 3.4 \\
\hline 5 & 11.3 & 11.4 & 6.1 & 0.9 & 14.0 & 11.6 & 8.7 & 3.4 & 12.5 & 10.9 & 9.5 & 5.9 \\
\hline 6 & 9.5 & 12.8 & 7.8 & 1.9 & 8.8 & 11.9 & 11.0 & 5.0 & 11.7 & 10.7 & 10.3 & 5.6 \\
\hline 7 & 7.8 & 13.2 & 11.3 & 3.9 & 6.2 & 10.0 & 12.8 & 9.5 & 8.5 & 10.1 & 11.2 & 9.2 \\
\hline 8 & 5.4 & 13.5 & 18.2 & 8.2 & 3.8 & 8.1 & 15.7 & 13.9 & 7.0 & 8.9 & 12.0 & 12.5 \\
\hline 9 & 3.2 & 11.5 & 23.2 & 23.2 & 2.7 & 5.4 & 15.2 & 24.3 & 4.9 & 7.3 & 11.8 & 19.7 \\
\hline 10 & 1.4 & 6.4 & 23.0 & 60.5 & 0.8 & 2.9 & 11.7 & 38.2 & 1.8 & 3.8 & 9.9 & 36.3 \\
\hline
\end{tabular}

Source: ECLAC, on the basis of special tabulations of household surveys.

${ }^{a}$ National total.

bight main cities.

avoid a greater deterioration in distribution over the period, since they tended to reduce the distances between the top and bottom deciles. Even so, Argentina shows the same systematic behaviour as other countries: the average transfers per recipient in the households tended to increase with the level of income, giving rise to differences which are very significant in some cases. These inequalities would appear to be explained by the interaction of a number of factors. Firstly, the coverage of social security systems is generally smaller among the lower-income segments. Secondly, the pensions received tend to reflect the income inequalities existing at the time when the recipients became eligible to receive them. Thirdly, as social welfare pensions are a public charge, they have often been eroded by inflationary processes. Finally, the higher degree of informal activity among the lower-income groups makes it more difficult for public social protection and assistance bodies to reach them and provide them with coverage. We thus see that transfers are generally not sufficient to offset the inequalities in primary distribution.

\section{Rates of employment, participation and household structure}

The influence of disparities in rates of employment on income distribution is clear both from cross-sectional analyses and from a dynamic perspective. As may be seen from table 4, the lowest income strata display rates of employment which are consistently lower than the average, but these rates increase as one moves up the income scale. Likewise, where an increase in income concentration was observed (Argentina, Brazil and Mexico), the relative levels of employment in the first decile deteriorated, while those in the top decile improved. In the case of Colombia (Bogota), however, the improvement in distribution observed is associated with an increase in the relative level of employment of the first strata, thus reducing the distance with respect to the top stratum.

Rates of participation behave in a similar manner, except that, for each particular year, their dispersion is greater than that of the corresponding rates of employment. As may be seen from table 4, the rates of participation are persistently and substantially below the average among the poorer households. Only in the case of Colombia (Bogota) are reductions in the disparities in rates of participation observed over time, this being the only case where incone concentration went down. Where concentration increased (Argentina, Brazil and Mexico), the differences in this variable persist. In Chile -a country which does not display improvements in distribution in spite of its sustained growth and the increases in rates of employment- the inequality in rates of participation increased in relative terms. ${ }^{8}$ Thus, despite an increase

\footnotetext{
${ }^{8}$ For more details of the evolution of this variable in Chile, see the corresponding case study.
} 
Latin America (five countrles): Relative indexes of factors reflecting participation in the labour market ${ }^{a}$

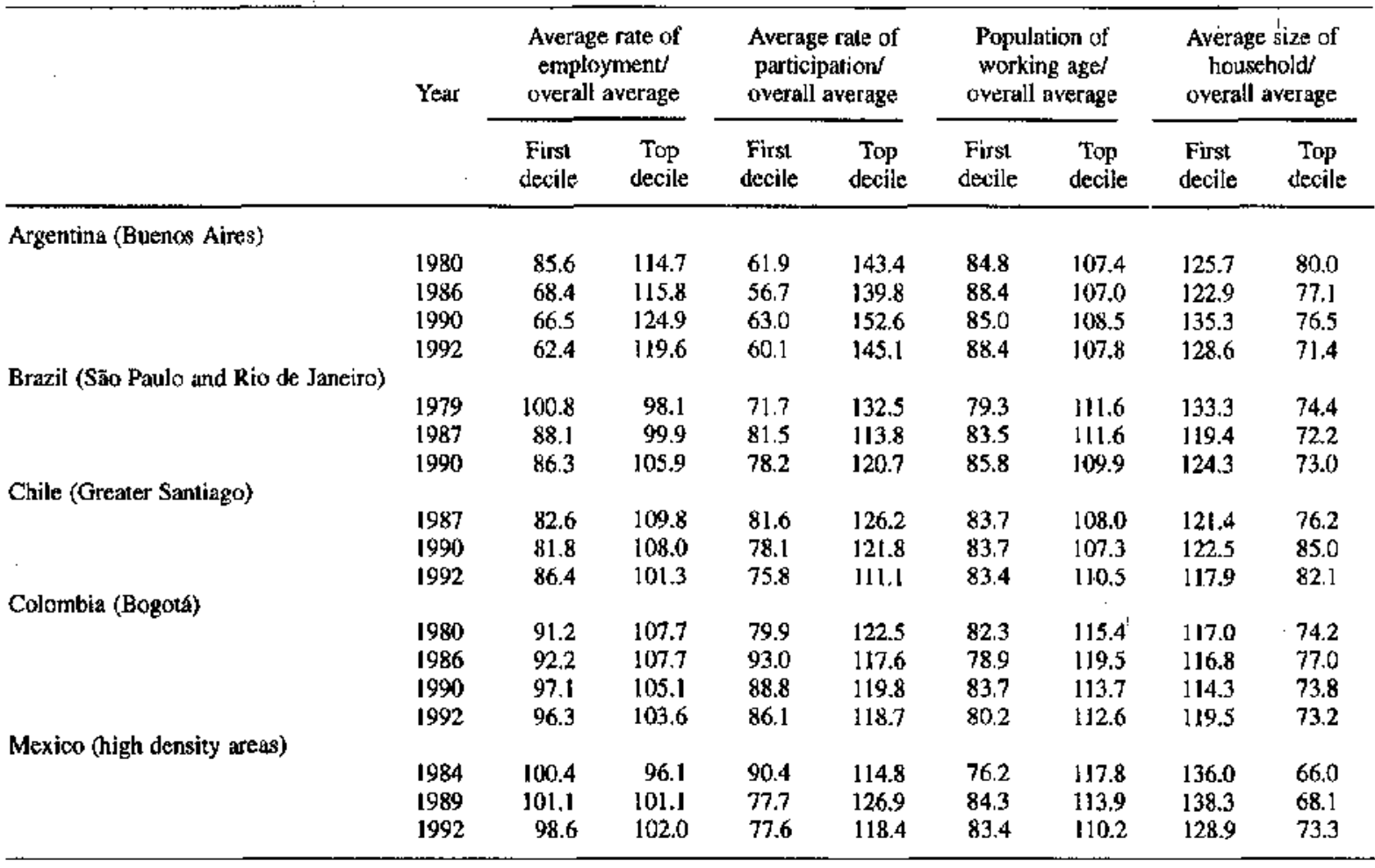

Source: ECLAC, on the basis of special tabulations of household surveys.

These jndexes are ratios between the average value of the variable for the decile in question and the corresponding overall average.

in absolute terms, the rate of participation of the first decile went down with respect to the mean in relative terms because of a bigger increase in the participation of the upper middle strata. Growth was thus not proportionately reflected in distributional gains.

The preceding paragraph refers to the participation in the labour market of those members of the household belonging to the population of working age. The relative size of this population also varies according to the deciles, however; in the households of the first strata there are relatively fewer persons who are of working age and can thus provide economic support. Thus, even if the rates of wages, employment and participation were the same, the first strata would continue to be less well off in relative terms. As we shall see in the following section, this reflects the greater relative presence of minors in the poorer households.

In short, among the lower income groups there is a smaller proportion of persons of working age who effectively participate in the labour market, either as employed persons or as persons seeking work. This limits the well-being of the household, since even if wages were the same as in higher strata the lower level of incorporation in the labour market reduces the total income generated by the household. As we shall see later on, this reflects the higher rates of inactivity observed in the lower-income strata, particularly among spouses.

\section{Size and structure of househoids and their influence on incorporation in the labour market}

The last two columns in table 4, together with figure 1, provide details of the size of households, which are seen to have more members in the first deciles. It is also noted that the upper deciles tend to be similar from one country to another. In the lower deciles, in contrast, the differences between countries are greater. With some variations, on average the size of the households in the poorest strata is $50 \%$ to $60 \%$ greater than in the upper deciles. This is a first indication that the differences between countries in terms 
FIOURE 1

Latin America (five countries): Average number of persone in household, by declles

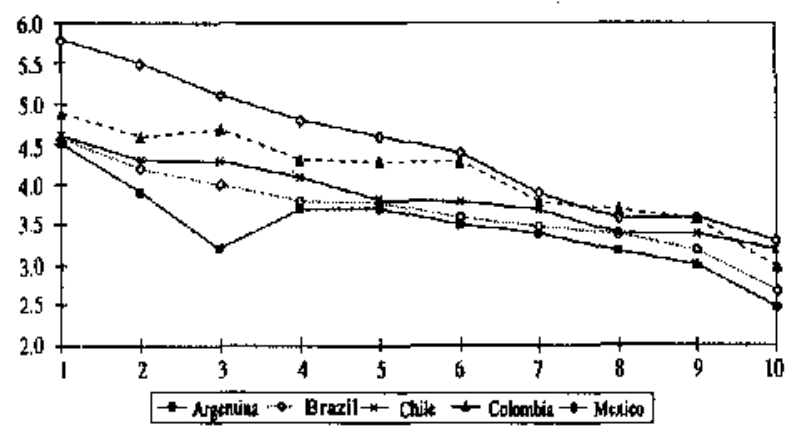

FFGURB 2

Latln Amorica (1ve countries): Number of minors per edult In household, by deciles

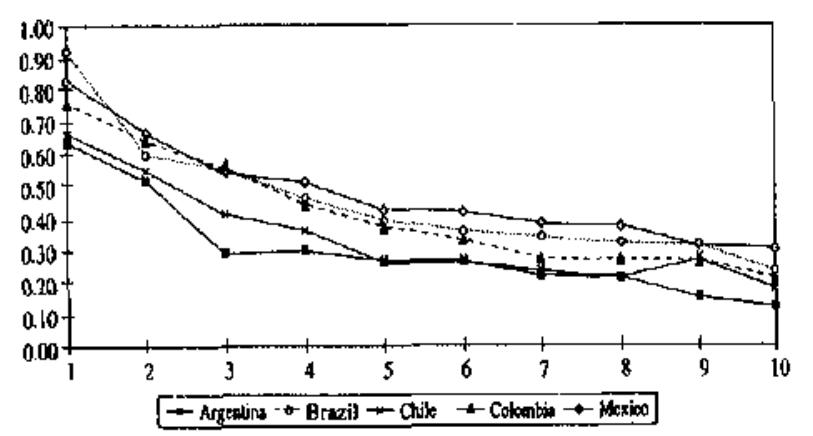

FIGURE?

Latin America (five countrles): Proportion of households in each declle where the spouse is not economically active (Percentages)

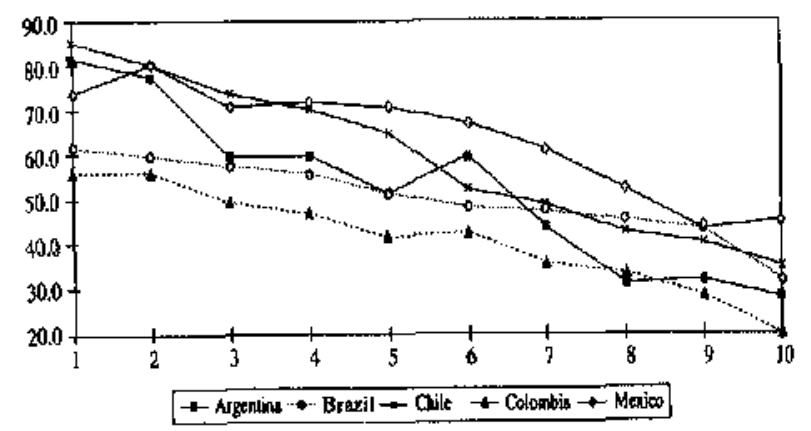

of population dynamics would appear to depend largely on the extent to which the lower income strata have reduced their fertility rates. In contrast, the upper income groups in the different countries appear to be at similar stages of progress in the demographic transition.

Because of this, poor households have a larger proportion of minors, as shown by figure 2 , which shows the proportion of children up to 11 years of age per adult in the household. The considerable difference between the first deciles and the upper strata is noteworthy. Even for countries at an advanced stage in the demographic transition, such as Argentina and Chile," there are differences of the order of $1: 4$ between the first decile and the top decile in terms of average number of children per adult in the household. This means that the burden of looking after minors is considerably greater among the poorer households: a factor which is reflected in turn in a high incidence of inactivity and low participation in the labour market among the spouses in those strata, as shown by figure 3 .

As may be seen from the figures, in some cases the percentage of spouses (of employed heads of household) who are not economically active in the first deciles is twice that of the top decile, reflecting serious inequality between strata as regards effective access to the labour market. Thus, the lower income groups face higher opportunity costs and lower bene-: fits when seeking to enter that matket. On the one hand, the greater burden of having to look after minors compared with households in higher deciles increases the opportunity cost both of seeking employment and of taking a formal job. This problem is frequently aggravated by insufficient availability or coverage of public and/or private services, especially day nurseries, kindergartens and schools. Secondly, the remunerations associated with the low educational levels reached by these segments do not adequately cover the costs incurred. This set of factors probably accounts for the lower level of incorporation into the labour market (especially the formalsector labour market) by spouses, which is reflected in high incidences of inactivity and low levels of employment among spouses in the first strata.

This situation has persisted over time and in general has tended to get worse, with an increase in the

\footnotetext{
${ }^{9}$ For a ranking of countries in the region according to their progress in the demographic transition, see CELADE/DB, 1996.
} 
Latin America (five countries): Number of households in each decile where the bead of household and his/her epouse are employed, as a proportion of the number of households where both are present (Percentages)

\begin{tabular}{|c|c|c|c|c|c|c|c|c|c|c|}
\hline & \multicolumn{2}{|c|}{ Argentina $^{\mathbf{a}}$} & \multicolumn{2}{|c|}{ Brazil $^{b}$} & \multicolumn{2}{|c|}{ Chile $^{b}$} & \multicolumn{2}{|c|}{ Colonbia } & \multicolumn{2}{|c|}{ Mexico } \\
\hline & 1980 & 1992 & 1979 & 1990 & 1987 & 1992 & $1980^{\circ}$ & $1992^{d}$ & 1984 & 1992 \\
\hline Tolal & 18.5 & 24.4 & 22.2 & 30.0 & 13.5 & 19.9 & 22.5 & 32,3 & 16.9 & 21,4 \\
\hline 1 & 2.9 & 3.1 & $2 \mathbf{1} .5$ & 20.9 & 2.0 & 2.8 & 10.1 & 14.6 & 10.1 & 15.1 \\
\hline 2 & 7.6 & 5.7 & 19.8 & 20.6 & 2.8 & 6.0 & 11.8 & 17.5 & 10.4 & 11.3 \\
\hline 3 & 10.1 & 10.2 & 18.2 & 24.8 & 4.5 & 9.8 & 12.6 & 25.7 & 14.9 & 18.4 \\
\hline 4 & 12.5 & 16.9 & 19.9 & 26.5 & 7.1 & 13.2 & 19.0 & 25.6 & 13.7 & 15.1 \\
\hline 5 & 13.0 & 22.8 & 18.3 & 28.1 & 10.0 & 16.8 & 19.5 & 32.7 & 13.1 & 17.0 \\
\hline 6 & 18.7 & 19.9 & 19.7 & 31.8 & 12.1 & 22.5 & 29.3 & 31.8 & 17.9 & 18.0 \\
\hline 7 & 25.1 & 33.8 & 21.6 & 33.1 & J6.5 & 27.4 & 28.0 & 35.9 & 18.8 & 23.6 \\
\hline 8 & 28.4 & 47.2 & 24.9 & 34.2 & 20.5 & 30.7 & 27.7 & 41.2 & 21.6 & 27.2 \\
\hline 9 & 35.5 & 49.6 & 27.7 & 37.7 & 27.5 & 34.4 & 31.9 & 45.2 & 22.5 & 36.4 \\
\hline 10 & 39.3 & 49.6 & 30.9 & 45.7 & 36.5 & 42.0 & 38.7 & 58.0 & 27.4 & 35.7 \\
\hline
\end{tabular}

Source: ECL.AC, on the basis of special tabulations of household surveys.

"Buenos Aires. "National total. "Seven main cities. ${ }^{\circ}$ Eight main cities.

relative differences. Table 5 shows, for two points in time, the percentage of households ${ }^{10}$ where both heads are employed. As may be seen from the table, substantial differences persist over time. The table shows firstly that the proportion of households where both heads are employed rises with the level of income in all cases. Secondly, it shows that on average this percentage has been increasing. Thirdly, in all the countries the increase in the percentage of households with both heads employed among the $30 \%$ poorest households is less than the average increase. Fourthly, the top $30 \%$ of the income distribution scale registers an above-average increase in this variable in all the countries. In short, the extent to which the spouses in the lower strata enter the labour market and take jobs is disproportionately low, while the opposite is the case in the upper strata. ${ }^{11}$ As a result, the benefits of economic growth, employment, productivity gains and the consequent increases in remuneration are limited to the upper deciles of the income distribution scale, while the remainder progress only very slowly.

The larger relative size of the poorer households and the greater relative presence of minors in them

\footnotetext{
to In each decile, the universe refers to households where both heads are present.

II In order to prove this hypothesis it is necessary to use longitudinaj-section surveys, which have only recently begun to be ap. plied in countries of the region.
}

affect not only their levels of participation in the labour market but also the direct and opportunity costs that these households incur if young people of working age remain in the educational system. This results in lower educational levels for these young people and ultimately lower future remuneration, thus reproducing a concentrated form of income distribution in following generations.

In short, the interaction of demographic characteristics and educational levels and their associated effect on remuneration give rise to a situation which, through differentiated access to the labour market, tends to bias the benefits of economic growth in favour of the upper deciles. The inertia caused by this is reflected in the low rate of progress in the improvement of income distribution.

\section{Conclusions}

There are of course other determining factors of income distribution which have not been analysed here, because of the approach adopted, the limitations of space and information, and the desire to center the analysis on certain factors with regard to which it is possible to formulate policies. The approach used highlights the way that household income is made up, unlike other studies which seek to explain how the income received is affected by some individual characteristics (education, sex, experience, type of employment, etc.) and the sectors to which the recipients belong. Some of these aspects have been dealt with 
here, but the analysis has concentrated on the eharacteristics of the households and their members as these relate to the formation of per capita household income. No analysis was made here of the different access that the various income strata have to capital stocks, housing and health services, among other items, which significantly condition the level of wellbeing of present and future generations.

Outstanding among the aspects dealt with here are the differences in terms of labour remuneration, education, rates of employment, access to the labour market and demographic factors, which determine significant inequalities. The main results are given briefly below.

Firstly, the mean factor incomes of the lower per capita income groups are substantially below those of the upper strata: a phenomenon which is associated, in the case of labour income, with significant differences in educational levels. Moreover, as other statis tics indicate, the lower income sectors are located in low-productivity segments of the labour market. This confirms the results obtained in earlier studies on inequalities of income between recipients.

Secondly, the rates of employment of the poorest groups are systematically below the average. Changes in distribution are largely associated with variations in levels of employment, and reductions in the relative differences in rates of employment have tended to be associated with a lower degree of income concentration.

Thirdly, there are big differences between the deciles in their degree of participation in the labour force. There is a systematic tendency for the poorest groups to register lower rates of participation. This is reflected in higher rates of inactivity, especially among spouses and, to a considerably lesser extent, among heads of household.

Fourthly, the foregoing is related with the age structure of the households in different deciles. Thus, according to various indicators the population of working age is considerably smaller in the poorest households. The proportion of children per adult is higher in them, so that they bear a heavier burden of caring for minors, and for women this raises the opportunity cost of participating in the labour market. ${ }^{12}$ This higher cost is compounded by lower benefits of participating in that market: a factor related with the levels of education attained.

Finally, it is important to bear in mind that no factor, when considered in isolation, can fully account for the prevailing distribution and the changes in it; the effects are multiplicative rather than additive.

\section{IV}

\section{Policy suggestions}

It may be gathered from the foregoing that strategies designed to influence income distribution should act jointly in four areas: i) generation of productive employment and increased demand for less-skilled labour; ii) policies to increase and maintain the income of the poorer strata; iii) reduction of the barriers facing the members of those strata when seeking to enter the labour market, and iv) aspects connected with the demographic dynamics of those segments.

The intensity of the actions to be taken in each of these fields will depend, of course, on the initial situation of each country. It must be emphasized, however, that improved distribution cannot be achieved through action on only one of the above aspects. In other words, the objective of achieving greater equity of income distribution goes beyond the limits of growth, labour and population policies and is rather the result of joint progress in all of them. In the following sections, policies are suggested for modifying income distribution in a progressive manner. The evolution of certain variables which make it possible to anticipate the evolution of income distribution in the medium term is also discussed.

\section{Medium and long-term policies in favour of better income distribution}

\section{a) Generation of productive employment and increased demand for less-skilled labour}

ECLAC has developed a proposal which addresses the main aspects connected with income distribution

12 Although the statistical analysis refers to "spouses" as, in principle, the second largest source of potential income of a household, the great majority of these spouses are women. 
in a consistent manner ( $\mathrm{ECLAC}, 1992$ and 1997). In the short term, this proposal emphasizes the importance of achieving high levels of employment and macroeconomic stability and thus avoiding the regressive consequences caused by fluctuations in the level of activity due to adjustment processes like those undergone by countries of the region in the $1980 \mathrm{~s} .{ }^{13}$ In a medium- and long-term perspective, this approach emphasizes, among other aspects, the creation of productive employment through sustained economic growth as one of the basic conditions for achieving greater equity over time. In line with this approach, policies are proposed for stimulating saving and investment and securing efficient resource allocation in the context of greater integration of national economies into world trade. Among these policies, an important place is occupied by the strengthening of the public finances with the aim of generating public saving for the non-inflationary financing of investment programmes. This public effort should be complemented with the development of agents of institutional saving, especially pension systems, and the establishment of a regulatory framework which will ensure a sound financial system that operates efficiently and effectively and channels saving to real investments. Maintaining a moderately high and stable real exchange rate is of crucial importance, not only as of the main instruments for promoting the export sectors and import-substitution activities but also, in conjunction with positive real interest rates in line with those prevailing in world markets, for keeping financial saving within the country and thus avoiding speculative capital flight. In this way it is possible to forestall fluctuations in levels of activity, with their consequent negative impact on investment, which are usually due to adjustment measures designed to cope with situations of external imbalance. In short, what is proposed is the establishment of a growth-oriented policy framework on the basis of greater linkages with the exterior and the recovery of levels of investment, mainly through the generation of national saving.

This approach recognizes, however, that because of the type of work offered to the low-income strata, higher growth is not necessarily reflected in rapid expansion of demand and hence in distributional pro-

${ }^{13}$ For an analysis of the distributive effects of shocks and shortterm policies, see Jiménez, 1997, which summarizes the results obtained by simulations, using general equilibrium models, for Argentina, Brazil and Colombia. gress, Because of this, policies are also outlined for the promotion of small and medium-sized enterprises, which are the main sources of formal-sector employment for the lower-income strata. One of the factors seriously limiting the development of these enterprises is the existence of segmented financial markets which restrict their access to credit. As a result, the investment possibilities of such enterprises depend to a large extent on the generation of internal surpluses, which reduces their growth and hence also the expansion of demand for less-skilled labour. New financial instruments are needed to overcome the inability of these enterprises to provide real guarantees, together with technical cooperation programmes and public support to improve their management capacity and ability to adopt technological advances, in order to free up the growth potential of small and mediumsized enterprises and, with it, the demand for labour (Held, 1995).

Unfortunately, the region's evolution in terms of saving, investment and growth between 1990 and 1996 was not enough to bring about significant increases in the generation of employment (ECLAC, 1997). Between 1991 and 1996, only four countries in the region achieved stable average annual growth rates over $4 \%$. Other countries accasionally achieved higher rates but were not able to sustain them. In short, as well as being only modest $(3.1 \%$ on average between 1991 and 1996), the region's growth has also been unstable, and this has been an important factor in the low growth of employment and the increases in unemployment (ECLAC, 1997). Using an indicator made up of five variables (unemployment, informal sector employment, wages in industry, minimum wages and productivity), the International Labour Organisation (ILO) reports that, out of a sample of 16 countries of the region, only five (Bolivia, Chile, Panama, Paraguay and Peru) registered ongoing positive progress in labour matters between 1990 and 1996, and only Chile registered advances in all the variables, including productivity; the remaining 11 countries, including the biggest and most populous economies of Latin America and the Caribbean, registered setbacks or failed to make progress in their indexes of labour progress over the period (ILO, 1996). In view of the foregoing, except in a few cases it is not possible to anticipate any significant improvements in income distribution in the region. On the contrary, because of the influence of the employment variable on distribution and the bigher inci- 
dence of unemployment in the poorer strata, income concentration will most probably increase in a substantial number of countries.

\section{b) Increasing and maintaining the income of the poorest households: education and transfers}

As already noted, the level of education significantly affects the remuneration of those who do manage to obtain employment, so that measures to promote expansion of the coverage of the educational system, increased rates of retention in the educational system and improvements in the quality of education must form a part of any policy designed to improve income distribution in the long term. In terms of income distribution, however, the results of these efforts will only materialize in the long run, as successive cohorts with higher levels of education begin to work and become more numerous. Training programmes designed to raise the level of skills of the poorest workers will probably show results more quickly, in the medium term. In addition, these programmes can heighten the efficacy of long-term policies, since there are inter-generational complementarities. For example, actual increases in household income as a result of improved wages thanks to training programmes would increase the tendency of the children to stay in school, thus avoiding their premature incorporation into poorly paid jobs and thereby giving them some hope of obtaining better incomes in the future.

There are also important complementarities with policies in other areas, as in the case of the provision of health services for the poor population. The improvement of such services strengthens the effects of education policy, since it makes possible greater continuity of presence in the school system and better use of the educational system by children and young people. Likewise, as a number of studies have shown, higher levels of education of mothers are reflected, among other things, in lower rates of infant morbidity and mortality (CELADE/DB, 1996). In both cases, the results in terms of distribution take a considerable time to materialize. The continued application of these policies and the maintenance of economic growth are therefore of crucial importance, since transitory reductions in the resources earmarked for these policies have permanent effects. For example, those who lose the opportunity to stay in the educational system today because of a transitory reduction in household income will find it difficult to re-enter the system in the future, so that their skills and hence their income could be permanently lower. Negative fluctuations in the resources for social policies thus tend to strengthen the inter-generational mechanisms for the transmission of poverty.

The region's past experience in this field unfortunately does not provide any grounds, except in a few cases, for anticipating progressive developments in income distribution. As various studies have pointed out, the resources earmarked for social policies have often been those which have suffered the biggest real reductions through public budget adjustments (ECLAC, 1994b; Cominetti, 1994), thus further aggravating the regressive distributive effects deriving from the recession. The lack of distributional progress in the 1990s can therefore be partly attributed to the macroeconomic adjustment phases undergone by most of the countries of the region in the 1980s.

The foregoing analysis refers to policies which seek, indirectly but nevertheless decisively, to affect the levels of income of those who obtain employment and also to improve income distribution too. Other policies, involving direct intervention, are also important however. The fixing of minimum wages is one of the most widespread practices, although there are divergent views on its efficacy and desirability.

In general terms, there is some degree of consensus that wage increases which exceed increases in productivity have distributional effects whose implications for levels of activity are not very clear but are generally negative. ${ }^{14}$ With regard to minimum wages, there are grounds for believing that real losses in them are associated with increases in the incidence of poverty and vice versa, even though the effects in terms of the Gini coefficient may not be readily discernible. Consequently, as long as the real growth of minimum wages is not higher than that of the average productivity of the economy, ${ }^{15}$ it may be anticipated that such growth would reduce the incidence of poverty, so that it continues to be an important policy tool (Jiménez, 1996; Morley, 1997).

Unfortunately, during the first half of the $1990 \mathrm{~s}$ real urban minimum wages evolved in such a way that no improvements in terms of distribution are to

\footnotetext{
${ }^{14}$ See Chisari and Romero (1996), Urani, Moreira and Wilicox (1997), Lora and Fernández (1996) and Jiménez (1997).

is It should be borne in mind that the increase in the productivity of small enterprises and the informal sectors, which are important users of less skilled labour, is usually below that of the rest of the economy.
} 
be expected by this means. Thus, as the ILO (1996) reports in respect of a sample of 18 countries of the region, in only four of them (Colombia, Costa Rica, Panama and Paraguay) did real urban minimum wages in 1995 exceed the 1980 level, and moreover, only in Costa Rica was the real growth of this variable in any way significant, so that on average in the region the real level of these minimum wages in 1995 was only equal to $72 \%$ that of 1980 , since they grew at a rate of almost zero $(0.8 \%$ per year) between 1990 and 1995.

A second alternative for modifying income distribution consists of direct transfers (mainly pensions and subsidies). The following brief analysis does not attempt to cover all the options for transfer mechanisms and their redistributive content, but merely to point out that, in view of the indirect and long-term nature of policies designed to modify income generation at its source, some actions have important potential for achieving progressive distribution in a shorter term and should therefore be taken into account. There have been numerous examples in the region of action seeking to transfer income and subsidies with the aim of alleviating the effects of certain factors responsible for poverty and regressive income distribution, and some brief comments are in order on the efficiency and efficacy of some of the main forms of transfers in this connection.

Reference is often made to the possibilities of redistributing income through the use of pension and retirement systems. An important digression is called for here. Firstly, as national case studies have amply shown, one of the main factors responsible for the precarious situation of these systems in some countries has been the lack of correspondence between contributions and benefits, which has resulted in a low degree of identification with the purposes of the systems and has encouraged under-declaration and evasion. ${ }^{16}$ An outstanding feature of the recent pension system reforms is the tendency to link contributions more closely with benefits, as a means of promoting the systems' solvency. This implicitly acknowledges that the introduction of redistributive criteria into pension systems can have a serious negative influence on their efficiency, solvency and financial stability. In short, such systems would appear to be an inefficient means of redistribution.

${ }^{16}$ See Iglesias and Acuña (1991); Uthoff and Szalachman (eds.) (1991, 1992 and 1994); Schulthess and Demarco (1993), and Uthoff (1995).
Secondly, in the experience of the region the coverage of pension systems is usually insufficient, so that if an attempt is made to carry out redistributive actions through them this will probably exclude a major part of the poorer strata. In other words, the efficacy of these systems as progressive redistribution mechanisms would appear to be far below what was expected, since their scope is less than that needed in order to reach the desired groups. Nevertheless, pension systems which include a solidarity-oriented financing component do have some redistributive potential for the middle and lower segments which come within their coverage, and this could be used provided that the problems of solvency are duly addressed.

Indeed, the current line followed in pension system reforms does not rule out policies of a redistributive nature, such as granting a minimum pension to those who, in spite of their contributions to the system, do not attain a certain level of income when they retire: in effect, poverty profiles indicate a greater incidence of such poverty among pensioners. Consequently, an important distributive and poverty-reducing function is played by measures to provide minimum pensions or pensions of a social welfare nature (in connection with accidents, sickness and widowhood, for example), along with the expansion of the coverage of pension systems and of social prom tection networks in general.

A second type of transfer which has aroused some interest recently is that connected with the greater incidence of unemployment in poor households. Table 6 shows the distribution of unemployed persons by deciles.

As may be seen from this table, there is a disproportionate concentration of unemployed persons in the first income deciles, even though the countries studied were going through different phases of the economic cycle in the years in question. Two unemployment situations which call for different policies must be taken into account when seeking to explain this. Firstly, the considerably higher incidence of unemployment in the first decile is considered to be due partly to the causal factors of chronic unemployment, which neither recovery of growth nor the maintenance of growth over time can significantly reduce. In this case, it is a question of hard-core poverty. Reducing the incidence of such unemployment would require, among other things, minimum employment programmes which would last longer than emergency 
TABLE 6

Latin America (five countries): Dlstrlbution of unemployed, by deciles

(Percentages)

\begin{tabular}{|c|c|c|c|c|c|}
\hline & Argentina, $1992^{2}$ & Brazil, $1990^{\circ}$ & Colombia, $1992^{c}$ & Chile, $1992^{d}$ & Mexico, $1992^{\mathrm{e}}$ \\
\hline Total & 100 & 100 & 100 & 100 & 100 \\
\hline 1 & 33.6 & 25.6 & 18.6 & 29.0 & 13.8 \\
\hline 2 & 19.2 & 13.1 & 15.4 & 15.3 & 17.0 \\
\hline 3 & 9.8 & 12.2 & 11.9 & 14.4 & 15.2 \\
\hline 4 & 14.0 & 13.0 & 11.0 & 9.2 & 10.2 \\
\hline 5 & 7.8 & 9.6 & 10.6 & 9.7 & 11.3 \\
\hline 6 & 5.1 & 6.7 & 11.0 & 5.6 & 7.4 \\
\hline 7 & 5.2 & 7.1 & 6.2 & 5.8 & 10.8 \\
\hline 8 & 0.9 & 5.6 & 7.0 & 3.9 & 2.5 \\
\hline 9 & 2.1 & 3.4 & 5.4 & 4.9 & 7.5 \\
\hline 10 & 2.4 & 3.5 & 2.7 & 2.2 & 4.2 \\
\hline
\end{tabular}

programmes and would provide a basic level of remuneration, although they should not be allowed to become a disincentive to the incorporation of the unemployed persons in question into the labour market in search of jobs with higher productivity and wage levels. The second type of unemployment is more closely associated with the economic cycle, but it too registers a higher incidence in the poorer groups. Transfers, or else emergency employment programmes, designed to replace income in transitory situations of unemployment would help to prevent income concentration from increasing in periods of recession.

The efficacy and efficiency of these schemes are greatly influenced by the forms of financing (unemployment insurance with individual contributions, use of public funds, etc.), the criteria for selecting the beneficiaries, the duration of the benefits and the extent to which they replace lost income. As it is not possible to make a detailed analysis here, we merely wish to emphasize that such tools are important because they would make it possible to prevent, at least in part, the further intensification of poverty and income concentration which periods of macroeconomic adjustment usually bring with them.

These tools, which are mainly of a compensatory or palliative nature, can usefully be incorporated in a global policy designed to guarantee a minimum level of family income, which would make it possible to overcome some shortcomings that such tools display when used alone (ECLAC, 1992). Thus, as noted, minimum wage policies have only partial scope, since they are restricted mainly to the urban formal sectors, while their impact on company profitability is greater in the case of small enterprises, which are the main users of less-skilled labour. Moreover, they have only a limited degree of efficacy in the event of recessions due to insufficient domestic demand. Consequently, they cannot be set at a very high level, nor can they be the only tool used. Similar problems of coverage are displayed by minimum and social welfare pensions and schemes for unemployment insurance and unemployment benefits. This means that it would be wise to think of using a set of tools designed to achieve a certain minimum level of family income through a combination of minimum wages and pensions, unemployment benefits and/or insurance, more family allowances and/or direct subsidies or transfers, or the provision of benefits in kind, as for example through the public school system. If the stipulated minimum level of family income were still not attained, these measures could be supplemented with transfers allocated in line with the incidence of the factors determining the severity of poverty and income concentration. Naturally, in order to do this it is necessary to establish methods of evaluating the situation of each family as regards income and/or needs through special registers, as a number of countries in the region have already done. ${ }^{17}$

Finally, a general comment may be made at this point on the question of the financing of transfers designed to promote redistribution or to relieve the effect of the factors affecting the severity of poverty.

\footnotetext{
17 An example of this is the operation of the Single Family Subsidy in Chile, based on the "economic and social profile card", which takes into account a tumber of factors in order to determine the eligibility of a family group to receive this subsidy.
} 
TARLE 7

Latin Amerlca (five countries): Distribution of children under 5, by declles

(Percentages)

\begin{tabular}{|c|c|c|c|c|c|}
\hline & Argentina, $1992^{\mathfrak{D}}$ & Brazil, $1990^{\circ}$ & Colombia, $1992^{c}$ & Chile, $1992^{d}$ & Mexico, $1992^{\circ}$ \\
\hline Total & 100 & 100 & 100 & 100 & 100 \\
\hline 1 & 22.6 & 20.4 & 18.4 & 19.3 & 17.2 \\
\hline 2 & 18.7 & 14.6 & 15.4 & 17.0 & 12.5 \\
\hline 3 & 10.9 & 12.6 & 14.7 & 12.6 & 13.2 \\
\hline 4 & 10.5 & 10.8 & 10.8 & 10.5 & 11.2 \\
\hline 5 & 7.9 & 8.9 & 8.9 & 8.0 & 11.2 \\
\hline 6 & 7.8 & 7.9 & 7.7 & 9.0 & 8.8 \\
\hline 7 & 6.9 & 7.7 & 6.3 & 6.4 & 7.5 \\
\hline 8 & 7.0 & 7.4 & 7.3 & 5.7 & 6.4 \\
\hline 9 & 4.0 & 5.7 & 5.6 & 6.5 & 5.9 \\
\hline 10 & 3.7 & 4.0 & 4.8 & 5.0 & 6.2 \\
\hline
\end{tabular}

Source: $\mathrm{ECLAC}$, on the basis of specinl tabulations of household surveys.

a Buenos Aires. ${ }^{b}$ São Paulo and Rio de Janeiro. ${ }^{c}$ Bogolá. $\quad{ }^{d}$ Greater Santiago. ${ }^{2}$ High-density areas.

The final effect these have on income distribution also depends on the effects of the method of tinancing the public expenditure involved. Many of the tax reforms introduced recently in the region have been aimed at increasing revenue collection and also improving the efficiency of the tax system by expanding participation or introducing indirect taxes such as the value added tax. Although there are many reasons for adopting this approach, the regressive nature of this method of financing must be borne in mind, for as a number of case studies show, financing increases in public expenditure through indirect taxes is the least desirable option from the strictly distributive point of view, ${ }^{18}$ because there are more possibilities of a shift in its incidence than in the case of direct taxes. Consequently, from this point of view it is desirable that future reforms should raise the direct rather than the indirect tax burden.

c) Reducing the barriers faced by the poorest sectors in seeking to participate in the labour market

As already noted, the opportunity cost for poorer households of participating in the labour market is very high, because of the greater relative presence of minors in the household. As may be seen from table 7 . the poorest $30 \%$ of households account for a major proportion -in some cases as much as $50 \%-$ of the total number of children under $5 .{ }^{19}$ Consequently, a

\footnotetext{
${ }^{18}$ See Chisari and Romero (1996), Lora and Fernández (1996), Urani, Moreira and Willcox (1997), and Jiménez (1997).

${ }^{19}$ This also means that transfers of cash, services or kind based on an allocation criterion which takes account of the presence of children in the household can have a high distributive content.
}

policy for the development of public or private instiutional arrangements for the care of minors would help the incorporation of spouses into the labour market by reducing one of the factors responsible for concentrated income distribution, namely, the lower relative rate of participation and the considerably higher rates of inactivity among spouses in poor households.

It is important to bear in mind some factors which condition the success of the above proposals. Firstly, not only is the opportunity cost of participating in the labour market higher for spouses from poor households but also, because of the low wages due to their low levels of skills, there is also less incentive for them to seek greater participation. Consequently, as well as taking measures to reduce the barriers which impede access to the labour market by spouses from lower-income households, it is necessary to establish training programmes specifically aimed at these persons. Secondly, the above considerations and measures are mainly on the supply side, and their results depend on an increase in the demand for labour due to economic growth and the provision of incentives for sectors which require less-skilled labour, such as small and medium-sized enterprises. In this connection, it was already noted earlier that only through joint action in the areas in question is it possible to achieve lasting improvements in distribution.

A second segment of the labour market which has problems of access is that made up of young people, among whom the incidence of unemployment is typically higher. In this case, lack of skills is one of the most important factors. A number of attempts are 
currently being made in the region to promote greater participation by organizations of private producers in the design and execution of training programmes, in order to secure a greater correspondence between the demand for particular skills and the content of such programmes (ECLAC/UNESCO, 1996). The aim is to help the graduates of training institutions to find jobs more quickly, to which end efforts are being made to get away from the passive scheme whereby training institutions provide instruction on the basis of their traditional capacities, which may not correspond with actual demand, and leave the problem of gaining access to employment entirely to those who attend these programmes.

While lack of skills among young people is an obstacle to their access to the labour market, it must at the same time be borne in mind that the poorest strata often have serious difficulties in keeping their young people in the school system, including secondary education, and subsequently in training institutions. For this reason, more flexible training curricula should also be considered as a means of providing technical or professional training at an earlier age to persons who do not wish or are not in a position to enter higher education.

\section{d) Aspects connected with population dynamics}

As noted earlier, demographic aspects have a significant influence on the distributive situation, even in countries like Argentina and Chile which have already made progress in the demograpbic transition towards lower levels of fertility. The poorer strata tend to have households with a larger number of members and a greater relative presence of minors, with the result that they contain relatively fewer members of working age.

A number of studies show that progress in the demographic transition has been more pronounced in the higher income strata; the poorer groups, in contrast, still register high rates of fertility, considerably above the average (CELADE/DB, 1996). The poorer strata also regulate their fertility less effectively, with smaller intervals between pregnancies, and both these facts -without mentioning other negative consequences- are reflected in greater instability of women's participation in the labour market.

Moreover, as many studies have shown, the poorest groups register a higher level of unwanted fertility: in other words, a larger proportion of them would have preferred to have fewer children than in groups enjoying a higher level of well-being. ${ }^{20}$ The educational level of mothers has been shown to be a variable that exerts a great deal of influence in this situation; the lower their level of instruction, the higher is their observed level of fertility and the greater is the proportion of unwanted pregnancies. In contrast, mothers with higher levels of instruction register lower rates of fertility and a lower proportion of pregnancies are unwanted. This highlights the considerable differences that exist in the access of different economic and social strata to family planning, which is reflected in inequality as regards exercising effective control over decisions that affect fertility. Thus, as special studies have shown, mothers with a lower level of instruction make greater use of traditional methods of birth control or simply do not use any birth control methods at all, whereas mothers with a higher level of instruction make more use of modern methods (CELADE/IDB, 1996). Consequently, policies which facilitate access to family planning and emphasize in advance the need for responsible parenthood are a necessary part of strategies designed to secure greater equity and better income distribution.

Secondly, as already noted, the efficacy of longterm policies such as those in the field of education depends largely on the health conditions of those entering the educational system. Determining factors in this respect are the health of the mother during the period of gestation and the health and nutritional state of the children in their early years. From this point of view, mother and child health and nutrition programmes also represent key elements in any distribution strategy, since although this may not be the main objective of the strategy it helps to create suitable conditions to enable the poorer groups to raise their skills and income in the long term. The level of instruction of mothers is also a variable which has a significant incidence with regard to infant mortality. The CELADEIDB study already referred to clearly shows that rates of infant mortality and morbidity are lower among the children of mothers with a higher level of education. Once again, this shows that an income redistribution policy must act on various fronts at once, thus acknowledging the multiple factors that determine income distribution.

20 See ECLAC (1992), CELADE/JDB (1996) and ECLACICELADE (1998). 
The policies mentioned above contain elements of both equily and income redistribution. They help to strengthen over time the effect of measures designed to increase the generation of income among the poorest sectors. If these policies also manage to reduce fertility in the most under-privileged strata, thus reducing the distance between the number of children wanted and the number actually born, this will tend to 'reduce the greater relative burden of looking after minors in these strata. This would make possible greater participation by spouses in the labour market, and if suitable training programmes are also carried out their income could also be improved.

Furthermore, the fewer the number of children, the smaller the amounts of resources needed to keep them in the school system and the lower the pressure to leave them unattended in order to look for work to help support the family. Both these factors help to keep minors in the school system so that they can hope to earn better incomes in the future.

In order for these demographic changes to take place, however, deliberate action is needed to promote greater access to family planning, and effective measures are required to strengthen the generation of income among the poorest sectors. If this is done, the changes will also be the result of the deliberate will of the poorer strata, who will take a different attitude to their fertility because they feel that this will contribute to their own future well-being.

(Original: Spanish)

\section{Bibliography}

Altimir, O. (1994): Income distribution and poverty through crisis and adjustment, CEPAL Review, No. 52, LC/G.1824-P, Santiago, Chile, Economic Commission for Latin America and the Caribbean (ECLAC).

Altimir, O. and S. Pintera (1977): Análisis de descomposición de las desigualdades de los ingresos primarios en países de América Latina, Santiago, Chile, ECLAC.

CELADE (Latin American Demographic Centre)/IDB (Inter-American Development Bank) (1996): $\mathrm{lm}$ pacto de las tendencias demográficas sobre los sectores sociales en América Latina, CELADE, Santiago, Chile.

Chisari, O. and C. Romero (1996): Distribución del ingreso, asignación de recursos y shocks macroeconómicos. Un modelo de equilibrio general computado para La Argentiva en 1993, "Financiamiento del desarrollo" series, No. 36, Santiago, Chile, ECLAC.

Cominetti, R. (1994): Gasto social y ajuste fiscal en América Latina, "Reformas de política pública" series, No. 20, Santiago, Chile, ECLAC.

ECLAC (1991): Magnitud de la pobreza en América Latina en los anos ochenta, "Estudios e informes de la CEPAL" series, No. 81, LC/G.1653-P, Santiago, Chile. United Nations publication, Sales No. S.91.II.G.10.

-(1992): Social Equity and Changing Production Patterns: An Integrated Approach, LC/G.1701 (SES.24/3), Santiago, Chile, 6 February.

- (1994a): Social Panorama of Latin America, 1994, LC/G.1844, Santiago, Chile.
- (1994b): El gasto social en América Latina. Un examen cuantitativo y cualitativo, "Cuadernos de la CEPAL" series, No. 73, LC/G.1854-P, Santiago, Chile, ECLAC.

-1995): Social Panorama of Latin America, 1995, LC/G.1886-P, Santiago, Chile.

(1996a): Social Panorama of Latin America, 1996, LC/G.1946-P, Santiago, Chile.

- (1996b): La sensibilidad del indicador de pobreza. Un analisis a partir de diferentes opciones metodológicas, LC/R.1657, Santiago, Chile, ECLAC.

(1997): The Equity Gap. Latin America, the Caribbean and the Social Summit, LC/G.1954/Rev. 1-P. Santiago, Chile. United Nations publication, Sales No. E.97.II.G.11.

ECLAC/CELADE (1998): América Latina: la transición demográfica en sectores rezagados, Santiago, Chile.

ECLAC/UNESCO (United Nations Educational, Scientific and Cultural Organization) (1996): Educación $y$ conocimiento, eje de la transformación productiva con equidad, Santiago, Chile.

Feres, J. C. (1995): La medición de los ingresos en la perspectiva de los estudios de pobreza. El caso de la Encuesta Casen de Chile: años 1987 a 1994. LC/R.1604, Santiago, Chile, ECLAC.

Held, G. (1995): Políticas de financiamiento de las empresas de menor tamaño: experiencias recientes en América Latina, "Financiamiento del desarrollo" series, No. 34, Santiago, Chile, ECLAC.

Iglesias, A. and R. Acuña (1991): Chile: experiencia con un régimen de capitalización 1981-1991, Santiago, Chile, ECLAC/United Nations Development Programme (UNDP). 
ILO (International Labour Organisation) (1996): Panorama Laboral 1996, Lima, Regional Office for Latin America and the Catibbean

Jiménez, L. F. (1996): La experiencia de ajuste durante la década de los ochenta en Latinoamérica, consecuencias distributivas $y$ diseffo de políticas sociales, in ECLAC/CLAD (Latin American Centre for Development Administration)/SELA (Latin American Economic System), Desarrollo con equidad. Hacia una nueva articulación de politicas económicas y so. ciales en América Latina y el Caribe, Caracas, Nueva Sociedad.

(1997): Distribución del ingreso, shocks y politicas macroeconómicas, "Financiamiento del desarrollo" series, No. 44, Santiago, Chile, ECLAC.

Jiménez, L. F. and N. Ruedi (1997a): Algunos factores que inciden en la distribución del ingreso en Argentina, 1980-1992. Un análisis descriptivo, "Financiamiento del desarrollo" series, No. 67, Santiago, Chile, ECLAC.

-(1997b): Algunos factores que inciden en la dis. tribución del ingreso en Colombia, 1980-1992. Un análisis descriptivo, "Financianiento del desarrollo" series, No. 68, Santiago, Chile, ECLAC.

(1997c): Algunos factores que inciden en la distribución del ingreso en Chile, 1987-1992. Un análisis descriptivo. "Financiamiento del desarrollo" series, No. 69, Santiago, Chile, ECLAC.

-(1997d): Un anallsis descriptivo de la distribucion del ingreso en Mexico, 1984-1992, "Financiamiento del desarrollo" series, No. 70, Santiago, Chile, ECLAC.

-(1997e): Un análisis descriptivo de factores que inciden en la distribución del ingreso en Brasil, 1979-1990, "Financiamiento del desarrollo" series, No. 71, Santiago, Chile, EClAC.

Lora, E, and C. Fernández (1996); Efectos de los shocks macroeconómicos y de las politicas de ajuste sobre la distribución del ingreso en Colombia, "Financiamiento del desarrollo" series, No. 38, Santiago, Chile, ECLAC.
Morley, S. (1997): Poverty during recovery and reform in Latin America: 1985-1995, Washington, D. C., IDB, mimeo.

Ocampo, J.A., M.J. Pérez, C. Tovar and F.J. Lasso (1998): Macroeconomia, ajuste estructural y equidad en Colombia, 1978-1996, Archivos de macroeconomía, No. 79, Santafé de Bogotá, República de Colombia, Departamento Nacional de Planeación, Unidad de Análisis Macroeconomico.

Pollack, M. and A. Uthoff (1990): Pobreza y empleo: un análisis del periodo 1969-1987 en el Gran Santiago, Documento de trabajo, No. 348, Santiago, Chile, Regional Employment Programme for Latin America and the Caribbean (PREALC)/LO.

Psacharopoulos, G., S. Morley, A. Fiszbein, H. Lee and B. Wood (1992): Poverty and Income Distribution in Latin America: The Story of the 1980s, Report No. 27, Washington, D. C., World Bank.

Schulthess, W. and G. Demarco (1993): Argentina: evolución deI sistema nacional de previsión social $y$ propuesta de reforma, Santiago, Chile, ECLAC/UNDP.

Urani, A. A. Moreira and L. D. Willcox (1997): Choques, respostas de política econômica e distribução de renda no Brasil, "Financiamiento del desarrollo" series, No. 43, Santiago, Chile, ECLAC.

Uthoff, A. (1995): Reformu a los sistemas de pensiones en América Latina y el Caribe, "Financiamiento del desarrollo" series, No. 29, Santiago, Chile, ECLAC.

Uthoff, A. and R. Szalachman (1991): Sistema de pensiones en América Latina. Diagnóstico y alternativas de reforma: Costa Rica, Ecuador, Uruguay y Venezuela, vol.1, Santiago, Chile, ECLAC/UNDP.

- (1992): Sistema de pensiones en América Latina. Diagnóstico y alternativas de reforma: Bolivia, Brasil, Colombia, Guatemala, Mexico, vol. 2, Santiago, Chile, BCLAC/UNDP.

-1994): Sistema de pensiones en América Latina. Diagnostico y alternativas de reforma: El Salvador, Honduras, Jamaica, Paraguay y Trinidad y Tobago, vol.3, Santiago, Chile, ECLAC/UNDP. 